\title{
Influence of relief dismemberment on surface - water infiltration and erosion conditions in Merkys River tributaries catchments
}

\author{
Algimantas Česnulevičius ${ }^{\mathrm{a}, \mathrm{b}}$, Lina Bagdžiūnaite - Litvinaitienè $^{\mathrm{b}}$, Andrius Litvinaitis ${ }^{\mathrm{b}}$ \\ ${ }^{a}$ Department of Hydraulics Vilnius Gediminas Technical University, Sauletekio ave. 11, Vilnius 10223, Lithuania \\ ${ }^{b}$ Cartographic Center, Vilnius University, M. K.Čiurlionio str. 21/27, Vilnius 03101,Lithuania
}

\begin{abstract}
The information necessary for assessment of water resources may be obtained by investigating the constituents of water systems: precipitation, runoff, infiltration. The latter two are largely affected by relief: its genesis, lithological structure, relief morphometric indices. The river catchments include relief complexes of variable genesis which differ also in their morphometric indices. This largely determines the surface runoff and infiltration properties of catchment and quantity of groundwater.

The surface inclination is one of factors affecting infiltration capacity. In sloping surfaces a considerable amount of precipitation flows down at a high speed. For this reason water infiltration in the upper part of the slope is by far lower than at the foot. Besides, the downstreaming water may accumulate in closed depressions. During rain-falls, it is possible to determine the amount of water, which gets into rivers and other water basins and in groundwater.

The energy of running water determines its impact on the slope, i.e. the actual slope erosion. It is determined by water mass and its flowing ratio. As a mass index we may take the largest amount of precipitation which falls down during a rainfall per unit of area.

The smallest energy of flowing water, which does erode the slope, equals $0.001 \mathrm{~kg} / \mathrm{m}^{2}$. In all other cases slope erosion takes place. The energy of water flowing down steep slopes is sufficient to start an intensive slope erosion and development of linear forms of erosion. The linear forms of erosion later stimulate a more rapid rain water flow into small river basins and, concomitantly, change the infiltration environment of the basin.

The aim of paper - evaluate of relief dismemberment influence on surface-water infiltration in Šalčia and Spengla Rivers catchments and flowing water impact on surface: rivers valley and hill slopes.
\end{abstract}

Keywords: water infiltration; erosion; morphometric indices; runoff.

\section{Introduction}

It is possible to gather all necessary information for evaluation of water recourses with the help of water systems integrate elements: precipitation, water flow, infiltration. The last two components are strongly effected by relief: its genesis, lithological structure, morphometric indicators. Various genesis relief complexes are spread in Lithuania territory. They differ with their morphometric and lithological (sediments) indicators. Normally, the indicators determine the surface flow and infiltration features of rivers and stream catchments as well as water gathering conditions and underwater amount. The last mentioned influences all rivers catchments landscape. Direct researches of rivers catchments infiltration processes and features are complicated and expensive. By applying direct researches it is difficult to cover wider areas. This kind of the problem most of the times is solved by applying two ways.

The first one could be referred to detailed researches in typical standard areas and their results extrapolation for wider territories. The second applicable method is indirect researches. One of the indirect researches options - diverse cartographical material analysis (cartographical analysis method). Currently, this kind of analysis could be performed by applying GIS, various-theme maps comparison as well as field cartography and observation (monitoring) in different points.

The last mentioned evaluation forms a possibility to involve the mathematics methodology maintained by differential equitation system describing dimensional underwater filtration processes. The received data allow to predict quite particularly the infiltration conditions in rivers catchments together evaluating unnecessary (for example, spread pollution)

Corresponding author: Algimantas Česnulevičius. E-mail address: algimantas.cesnulevicius@gf.vu.lt

http://dx.doi.org/10.3846/enviro.2014.075

(C) 2014 The Authors. Published by VGTU Press. This is an open-access article distributed under the terms of the Creative Commons Attribution License, which permits unrestricted use, distribution, and reproduction in any medium, provided the original author and source are credited. 
phenomenon and its coverage. For the simulation process it is necessary to have detailed boring localization, water layer sole, ridge and thickness and groundwater free surface, pressure watery layer piezometric surface and water layer filtration coefficients values data [1]. These findings are received from the monitoring borings; their number is not big. Whereas, specific infiltration conditions and water amounts could be evaluated by invoking indirect cartographical methods, especially by analysis of small rivers catchments.

\section{The object of the research}

Lithuanian Geology Survey has saved the data and has evaluated Lithuania groundwater dynamical resources [2]. On the other hand, these data is already broad-brushed; into the small rivers catchments happening infiltration most of the times is generalized ignoring the surface morphometric indicators. Two Merkys river affluent catchments were chosen for the research: Šalčia and Spengla (Fig. 1). The catchment of Šalčia River includes few genetic genesis relief types (Fig.2). Eastern and southern part of the catchment, there are extended end moraine hill formation, ravines as well as small till basins and glacier edge band formed during Medininkai glaciation formation. In eastern part of the catchment dominate large middle-height and high hills as in southern part - large low and middle-height [3]. In northern west part of the catchment there is a sandy glaciolacustrine glacial plain; its surface northern part has formations of eolian processes continental strip of dunes. Glaciolacustrine plain is flat; within low, middle-height and high eolian dunes.

Spengla catchment also includes few different genesis relief areas. Northern west and west catchment parts are covered by Nemunas ice-age formations with glacier edge hills, waves, hollows and kettles. In here dominate medium size low and middle height hills. Central and eastern catchment parts have sandy-gravel glaciofluvial cover and southern part is widespread sandy glaciolacustrine plain. In glaciofluvial plain dominate waves and medium size low hulls. They are varied by a big number of sinkholes, hollows, kettles and dry ravines. Glaciolacustrine plain is a flat previous shallow glaciolacustrine basin bottom (Fig. 2).

\section{Research methodology}

Quantitative assessment of groundwater in river basins is based on the evaluation of several environmental components (the structure of precipitation, evaporation, runoff, surface split, sediments and land use). Empiric formulas that describe the quantitative values of these components [4] are used for assessment. In order to assess the infiltration speed, formulas for long-term precipitation are used:

$$
V=k \times(s+h) / \mathrm{s}
$$

Formulas for one rainfall precipitation:

$$
V=k+(k h / s)
$$

where $V i$ - water infiltration speed; $k$ - filtration coefficient of the deposits; $s$ - precipitation column height (cm); $h-$ suction force of the capillary meniscus; $t$ - time to produce the column heights $(\mathrm{sec})$.

When the surface of sediments is very quickly saturated with water and the size:

$$
k h / s \rightarrow 0,
$$

become close to 0 . It is therefore appropriate to use a simpler formula:

$$
V=k \text {. }
$$

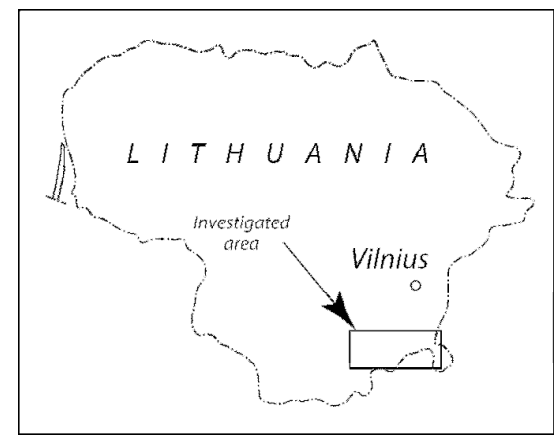

Fig. 1. Investigateed area - Šalčia and Spengla rivers catchments 


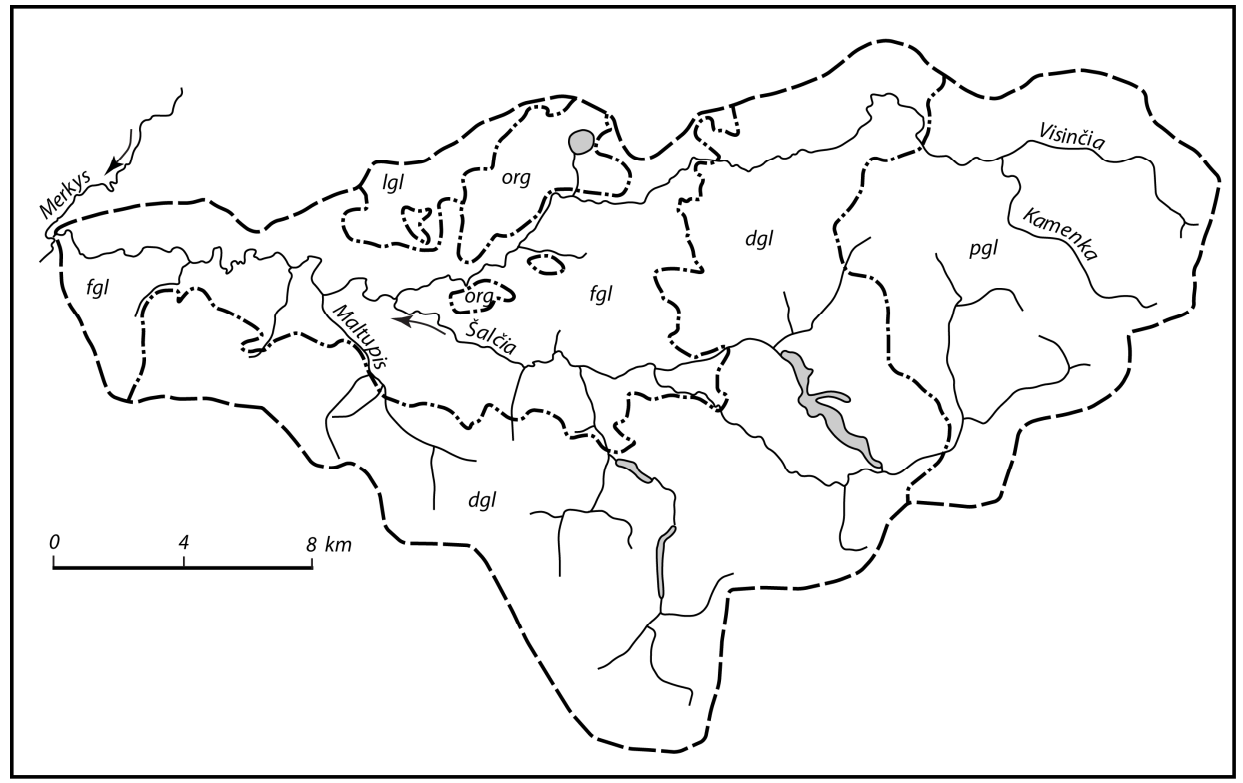

Fig. 2. Genetic relief complexes of Šalčia River catchment: $p g l$ - glacial edge; $d g l$ - ground moraine; $f g l$ - glaciofluvial; $l g l$ - glaciolacustrine; org - organogenic

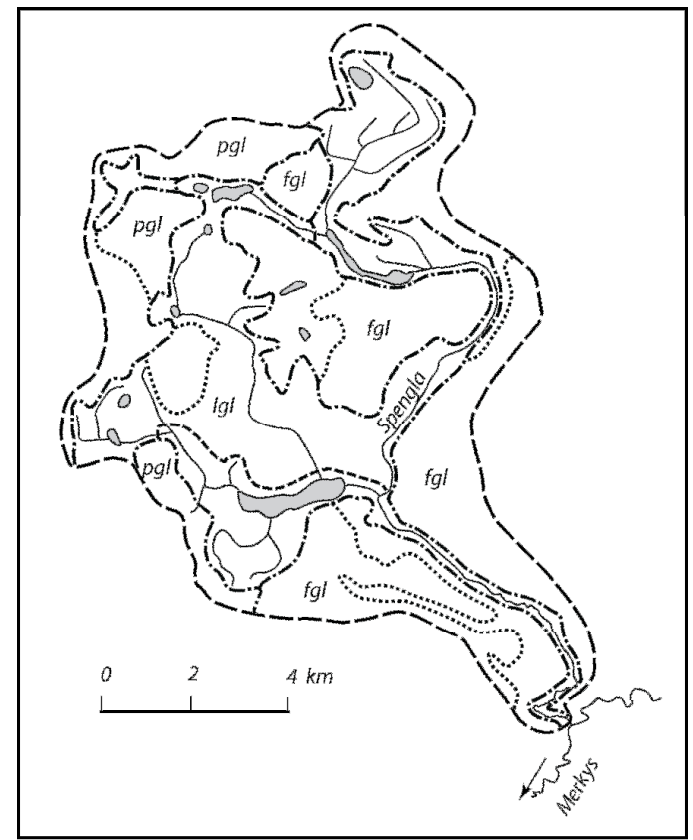

Fig. 3. Genetic relief complexes of Spengla Rriver catchment. Symbols alike as in Fig. 2.

Gravitational water resource was assessed using the formula:

$$
V_{g r}=m \times V,
$$

where $V_{g r}$ - gravitational water resources; $m$ - waterback coefficient; V - surface water volume (precipitation layer) [5], [6].

The amount of precipitation in river basins is estimated in several aspects: its quantity, duration, intensity and frequency. Data of the nearest meteorological stations is used for the research and is either interpolated or extrapolated. It is quite difficult to assess the quantity of effective precipitation, leading to the actual river basin water resources. For this it is necessary to know the precipitation retention and interception volumes. In addition, the evaluation of evaporation and infiltration in river basins require individual outside research. An important indicator determining underground water resources is surface sediments infiltration features. Large-scale (1:10 000) lithological and soil maps are suitable for the sediment assessment. Precipitation infiltration conditions are determined by the horizontal and vertical river basin surface diffusion. One of the most important surface diffusion indicators that influence precipitation infiltration is a surface slope. Even a slight surface inclination leads to a rapid direct precipitation water run off the slope or its lower infiltration.

One of the most important factors influencing infiltration is the gradient of the surface. In oblique surface great part of the precipitation quickly flows towards lower part of the slope. It is the reason why water infiltration level in higher part is significantly lower than in in base of the hill. What is more, the water flowed down from the hill could gather in blind 
descents. Part of this water outright passes to water catchments. It is possible to measure the amount of water outright reaching rivers and other water catchments during the rain showers. It is necessary to evaluate the speed of downhill flowing water:

$$
V=g \times \sin \alpha \times h^{2} / 2 v,
$$

where $g$ - free fall acceleration, $\alpha$ - inclination of the slope, $h$ - thickness of the precipitation, $v$ - kinetic molecular tenacity coefficient.

This dimension could be counted according to this formula:

$$
N \times v=m / p,
$$

here $m$ - the coefficient of liquid tenacity, $p$ - density of the liquid.

Water kinetic tenacity coefficient is equal to 1 , so the speed of the water going down the slope could be evaluated using this simple formula:

$$
V=g \times \sin \alpha \times h^{2} / 2 .
$$

The energy of the flowing water determines its effect for the slope itself, it means, its real erosion. Because of this water energy the surface sediments cover is washed and the surroundings infiltration features change [7].

\section{Results}

Relief genesis. Šalčia and Spengla rivers catchments include the glacier edge, glaciofluvial, glaciolacustrine, erosive, fluvial, eolian, and organogenic relief complexes. Moreover, relief complexes age differs. Eastern part of Šalčia catchment was formed during the end middle Pleistocene period (70 000 years ago), as the rest of the Šalčia and Spengla catchments parts are much younger - 12 000-18 000 year; the age of the relief has influenced the surface sediments decay level and directly effects the infiltration conditions (Table 1).

Morphometric features of relief. The rugged relief is typical to the formations of the glacier edge. Eastern part of Šalčia catchment distinguishes with vertical and horizontal dissections. Long slopes of the relief forms result fast surface flow during the rain showers. Precipitation infiltration, as normal, happens in down parts of the slopes as well as in hollows. At the foot of the slopes also the outwash erodible gathers; the fine-grained sand and silt sediments dominate here. Their covers distinguish with worse filtration qualities (Table 2).

Much better filtration conditions could be indicated in plane and wavy glaciolacustrine, organogenic as well as flat glaciofluvial planes and eolian dune solids. The fine-grained and middle-grained sands dominate in here. The peat and humus occur in closed trough. They significantly change the infiltration conditions: an intensive evaporation processes happen here. However, the sand cover under them distinguishes with a good infiltration.

Sediments distribution. The best infiltration conditions are in researched rivers catchments middle-stream and downstream parts. Within Spengla river catchment middle-stream part the thick rough glaciofluvial sediments layers exist (of 812 meters). Within flatten middle-stream and mouth parts of Šačia as well as in down-stream of Spengla catchments there are fine-grained sand sediments. There are significantly good precipitation infiltration conditions in Northern part of Šalčia catchment. Middle size eolian relief forms dominate here (Table 3).

Using long-term Varèna meteorology station data the levels and amounts of possible precipitation infiltration have been evaluated. In eastern (up-stream) Šalčia catchment part infiltration module are about $1-3$, in middle-stream part - 5-7 and in the down-stream increase to 7-9 1/. $\mathrm{km}^{2}$. In the up-stream Spengla River catchment part infiltration module are about $0-$

\begin{tabular}{|c|c|c|c|c|}
\hline \multirow[t]{2}{*}{ Relief genetic complexes } & \multicolumn{2}{|l|}{ Šalčia River } & \multicolumn{2}{|c|}{ Spengla River } \\
\hline & $\mathrm{km}^{2}$ & $\%$ & $\mathrm{~km}^{2}$ & $\%$ \\
\hline Glacial edge & 74.9 & 10 & 31.1 & 21 \\
\hline Ground moraine & 314.58 & 42 & - & - \\
\hline Glaciofluvial & 37.45 & 5 & 77.1 & 52 \\
\hline Glaciolacustrine & 179.76 & 24 & 25.2 & 17 \\
\hline Erosion & 29.96 & 4 & 0.7 & 1 \\
\hline Eolian & 59.9 & 8 & - & - \\
\hline Fluvial & 29.94 & 4 & 1.8 & 1 \\
\hline Organogenic & 22.47 & 3 & 12.4 & 8 \\
\hline
\end{tabular}
1, in middle-stream part - 7-9 and in down-stream part to 5-7 l/s km² (Fig. 4).

Table 1. Distribution of different relief genetic complexes in Šalčia and Spengla rivers catchments 
Table 2. Distribution of different morphometric relief types in Šalčia and Spengla rivers catchments

\begin{tabular}{|c|c|c|c|c|}
\hline \multirow[t]{2}{*}{ Morphometric relief types } & \multicolumn{2}{|c|}{ Šalčia River } & \multicolumn{2}{|c|}{ Spengla River } \\
\hline & $\mathrm{km}^{2}$ & $\%$ & $\mathrm{~km}^{2}$ & $\%$ \\
\hline Small low & 28.07 & 4 & 27.82 & 19 \\
\hline Small medium height & 3.94 & 1 & 6.26 & 4 \\
\hline Small high & - & - & - & - \\
\hline Medium size low & 2.6 & 1 & 20.56 & 14 \\
\hline Medium size medium height & 3.54 & 1 & 0.26 & 1 \\
\hline Medium size high & 5.41 & 1 & - & - \\
\hline Large low & 142.31 & 18 & - & - \\
\hline Large medium height & 239.68 & 31 & - & - \\
\hline Large high & 44.94 & 6 & - & - \\
\hline Waves & 142.31 & 16 & 70.63 & 48 \\
\hline Flat plains & 239.68 & 21 & 19.9 & 14 \\
\hline
\end{tabular}

Table 3. Distribution of different surface sediments in Šalčia and Spengla rivers catchments.

\begin{tabular}{lllll}
\hline Surface sediments & $\begin{array}{l}\text { Šalčia River } \\
\mathrm{km}^{2}\end{array}$ & $\%$ & $\begin{array}{l}\text { Spengla River } \\
\mathrm{km}^{2}\end{array}$ & $\%$ \\
\hline Sand & 164.78 & 22 & 91.41 & 64 \\
Sandy loam & - & - & 0.97 & 7 \\
Sandy loam/ sand & 142.31 & 19 & 7.37 & 5 \\
Sandy loam/ loam & 277.13 & 35 & 17.78 & 12 \\
Humus/ sand & 14.98 & 2 & 3.56 & 2 \\
Humus/ loam & 7.52 & 1 & 2.11 & 1 \\
Peat / sand & 144.34 & 19 & 13.64 & 9 \\
Peat / sandy loam & 0.47 & 1 & - & - \\
Peat / loam & 4.08 & 1 & - & - \\
\hline
\end{tabular}

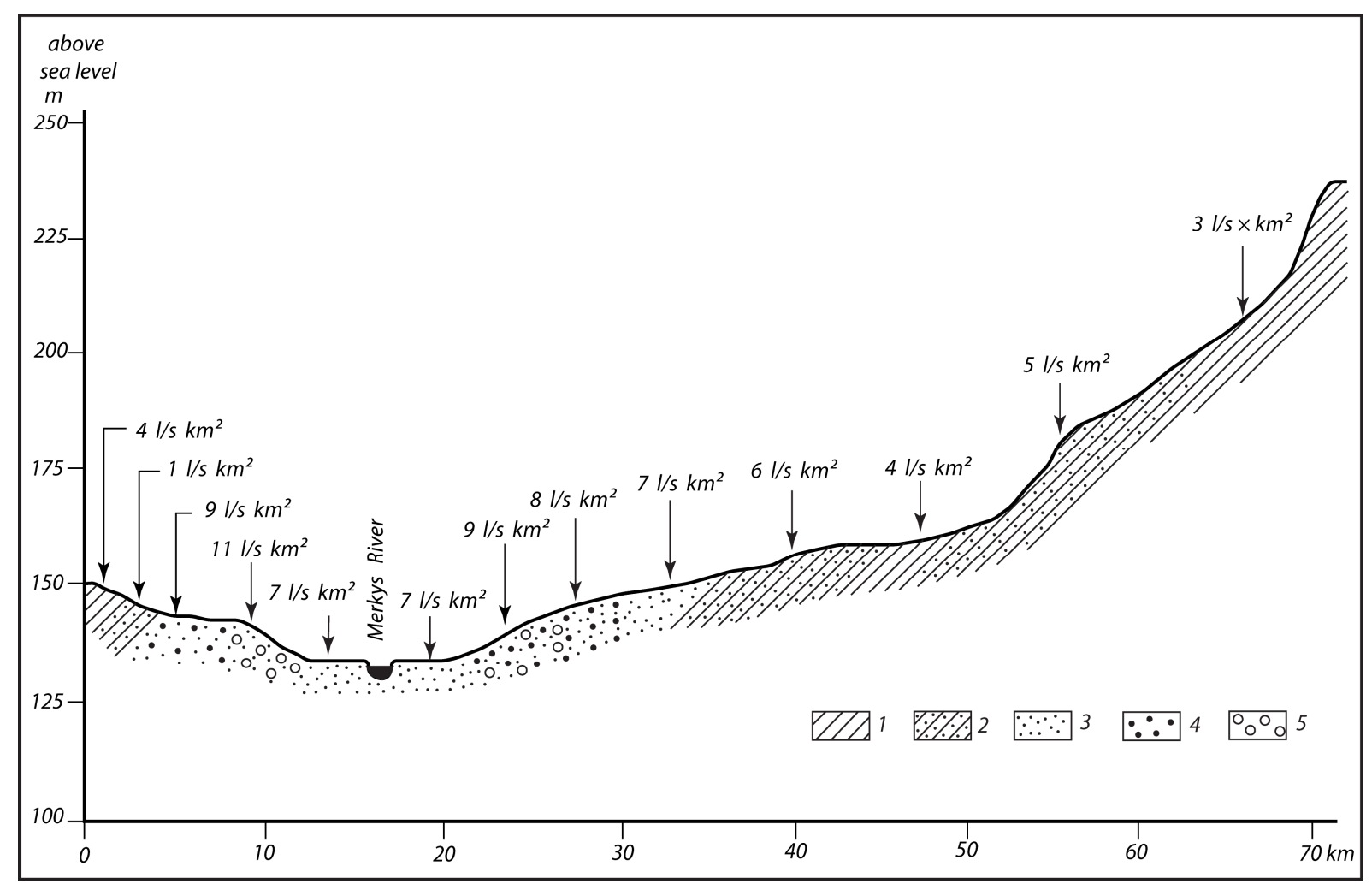

Fig. 4. Distribution of infiltrate modules in Spengla and Šalčia river catchments cross - section: 1 - loam; 2 - sandy loam; 3 - sand; 4 - gravel; 5 - pebbles 
According to evaluation of infiltration conditions and the amount of infiltrating water the Šalčia and Spengla rivers catchments infiltration zoning was proceeded. These catchments include the territories where Middle and Late Pleistocene glacier left sediments and the late glacier as well as Holocene sediments. There were 3 infiltration zones (Fig. 5).

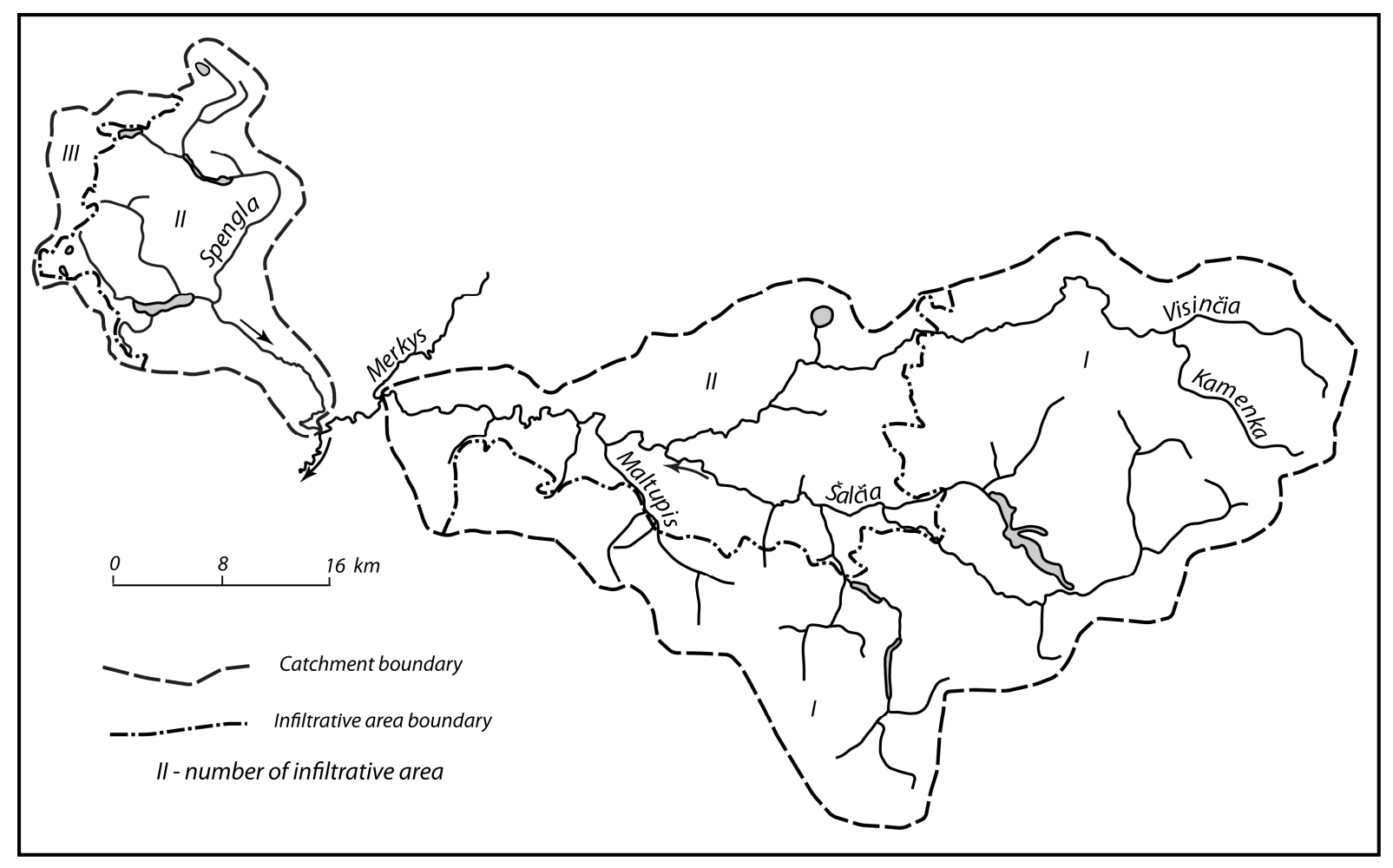

Fig. 5. Distribution of infiltrative areas in Šalčia and Spengla rivers catchments

The first one distinguishes with middle infiltration conditions. These have been formed by mixed and various mostly fine-grained surface sediments. Moreover, long relief forms slopes increases the surface water flow during the rainfall and accordingly narrows precipitation water infiltration surfaces. It means that water infiltration happens in lowest parts of the slopes and in kettles and hallows. Most of the precipitation fall in the first zone, however, because of the cultivated fields the steaming is more intensive.

The second zone distinguishes with good infiltration features. In surface are most dominating are fine-grained and middle size sands. The relief is smooth and wavy, that results very light surface flow during the rainfall. Moreover, in forestry areas the convection atmosphere evaporation are forming. These evaporation results the increase of precipitation level up to 10 percent.

The third zone differs with bad infiltration features resulted by mixed sandy loam and loamy sediments. Infiltration conditions being worsen by significant dissolution of relief increasing the surface flow. This zone is under "precipitation shadow" influence - distal Dzūkai Highland slope that already decreases the infiltration features quality level.

\section{Conclusion}

Even 41 percent of Šalčia catchment is covered by the sediments distinguishing with good infiltration features (infiltration module $7-9 \mathrm{l} / \mathrm{s} \mathrm{km}^{2}$ ) - coarse-grained and middle- grained sand. Various mixed sand and sandy loams or gravel covered with peat and mud areas that infiltration features are worse $\left(5-7 \mathrm{l} / \mathrm{s} \mathrm{km}^{2}\right)$ makes about 21 percent of catchment territory. Till formations characterized with bad infiltration characteristics $\left(-0.4-31 / \mathrm{sm}^{2}\right)$ covers 38 percent of Šalčia catchment area.

66 percent of Spengla catchment is covered by sediments distinguishing with good infiltration features (infiltration module $7-9 \mathrm{l} / \mathrm{s} \mathrm{km}^{2}$ ) - coarse and middle-grained sand including gravel additions. Mixed sand and sandy loam as well as sand covered with peat and humus that infiltration features are worse $\left(4-7 \mathrm{l} / \mathrm{s} \mathrm{km}^{2}\right)$, reach 19 percent of catchment area. Till formations distinguishing with bad infiltration features $\left(-0.1-4\right.$ 1/s km$\left.{ }^{2}\right)$ reach 15 percent of Spengla catchment zone.

Analysed Šalčia and Spengla catchments were divided into three infiltration zones clearly differing with infiltration water amounts. First zone (Medininkai Highland and Eišiškès Plateau distinguish with middle type infiltration features; second zone (Merkys Middle-stream Plain) characterizes with good infiltration qualities and the third zone (Dzūkai Highland distal slope) - distinguishes with bad infiltration conditions. 


\section{Acknowledgement}

The authors of the article sincerely thanks for VGTU graduate student Mindaugas Kuosa for his assistance during outside researches.

\section{References}

[1] Juodkazis, V.; Gregorauskas, M.; Mokrik, R. 2012. Regioninè hidrogeodinamika: požeminio vandens telkiniai ir ištekliai [Regional hydrodynamic: pools and resources of groundwater]. Vilnius: Vilnius University Press. 248 p. ISBN 978-609-459-113-6

[2] Giedraitienè, J. 2009. Gruntinio vandens ištekliai [Shallow groundwater resouces], in Lietuvos požeminès hidrosdferos monitoringas 2008 [Groundwater monitoring in Lithuania 2008]. 10-11. Vilnius: Lietuvos geologijos tarnyba. ISSN 2029-3186.

[3] Česnulevičius, A. 1999. Lietuvos reljefas: morfografiniai ir morfometriniai aspektai [Lithuania relief: morphographic and morphometric aspects] Vilnius: Institute of Geography. 196 p. ISBN-9986-953-01-4.

[4] Juodkazis, V. 1992. Požeminio vandens ištekliu įvertinimo pagrindai [Fundaments of graound water resource evaluation]. Vilnius: Science. 216 p. ISBN5-420-01-062-3.

[5] Litvinaitis, A.; Šaulys, V. 2011. Research methodology of sediment aeration zone of the river bank buffer area, in Proc. 17th international scientific conference Research for rural development 2: 141-145. ISSN 1691-4031.

[6] Česnulevičius, A. 2011. Method for evaluation water budget in small river catchments, in Proc. of the $8^{\text {th }}$ International Conference Environmental Engineering 2: 538-542. ISBN 978-9955-28-828-2.

[7] Česnulevičius, A. 1998. Vilniaus miesto mažujų upelių baseinų infiltracinès savybès ir jų sąsaja su reljefo erozija [Infiltration properties of small river basins in Vilnius and their relatioship to relief erosion], Geografija [Geography] 34(1): 5-10. 